\title{
E्Everearão
}

\section{Para Além da Justa Medida: Arendt, a ética, o desejo e a educação}

\author{
Marcia Regina Fogaça' \\ 'Universidade de São Paulo (USP), São Paulo/SP - Brasil
}

RESUMO - Para Além da Justa Medida: Arendt, a ética, o desejo e a educação. Este artigo busca extrair, de uma leitura psicanalítica, algumas implicações para a educação de ideias de Hannah Arendt, através do estabelecimento de um diálogo entre a proposição lacaniana de uma ética do desejo e reflexões arendtianas acerca de uma moral da verdade e do pensamento. Para tanto, são identificados pontos de contato, disjunção e ressonâncias entre as articulações arendtianas e a proposta psicanalítica, assim como são tecidas algumas considerações sobre o exemplo, colocado por Arendt como alternativa ao mandamento moral enquanto direcionamento ao bem. Palavras-chave: Moral. Ética. Desejo. Exemplo. Educação.

ABSTRACT - Beyond a Just Measure: Arendt, the ethics, the desire, and the education. This paper intends to extract, from a psychoanalytical reading, some implications for the education of Hannah Arendt's ideas through the Lacanian proposition of the ethic of the desire and Arendtian reflections about moral of the truth and that of the thought. For this reason, contact points, disjunction and resonances between Arendtian articulations and the psychoanalytical proposal, as well as some considerations are commented on the example placed by Arendt, as an alternative to the moral commandment while directed to well.

Keywords: Moral. Ethics. Desire. Example. Education.

Educação \& Realidade, Porto Alegre, v. 38, n. 2, p. 413-431, abr./jun. 2013.

Disponível em: <http://www.ufrgs.br/edu_realidade> 
Para Além da Justa Medida

O texto Verdade e Política - tomado para estas considerações - foi escrito por Hannah Arendt (1979) em fevereiro de 1967 para esclarecer polêmicas e mentiras geradas em torno de um outro anteriormente publicado (1963) sob o título Eichmann em Jerusalém, um relato sobre a banalidade do $\mathrm{mal}^{1}$. Portanto, o pano de fundo do texto arendtiano sobre a verdade é a grande questão sobre a relação entre pensamento e moralidade que permeia o outro, sobre Eichmann, qual seja: se "[...] não apenas [...] a ausência de pensamento pode contribuir para que se dê o mal em sua forma extrema, ilimitada, banal, mas também se, de algum modo, o pensamento pode evitá-lo" (Correia, 2007, p. 49).

Da perspectiva psicanalítica, vou partir de dois recortes do texto Analisis Terminable y Interminable (Freud, 1989 [1937]) que colocam a experiência analítica, embora não seja esse o tom dado ao texto por Freud, sob questionamentos que dizem respeito à ética e, nesse sentido, também à educação no que esta pode ser considerada como transmissão de cultura e de subjetividade e, consequentemente, de formas de agir. Primeiro ponto: a questão da possibilidade do domesticamento total das pulsões e se esse poderia ser considerado o objetivo para uma psicanálise, um sinônimo de cura, assim como o poderia ser o objetivo da educação. Segundo ponto: dado que a psicanálise afirma que a experiência analítica produz, naquele que por ela passa, um estado no eu que não acontece espontaneamente, esse estado criado constitui a diferença entre uma pessoa que se submeteu a uma análise de uma outra que nunca o fez. Em que consistiria essa diferença?

Freud já havia chegado à época de tais considerações à ideia de pulsão de morte ${ }^{2} \mathrm{e}$ à proposição do aparelho psíquico como relações entre as instâncias que o constituem, a saber, o isso, o eu e o supereu. Sendo assim, já não alentava a esperança da possibilidade de que a resposta à primeira questão fosse afirmativa, porém, mesmo assim - ou talvez por isso mesmo - empreende o exercício de demonstração da impossibilidade de realização plena, completa, de um objetivo assim colocado. Demonstração que vale tanto para a cura quanto para a educação. Um dos componentes de tal impossibilidade se localiza na diferença entre os indivíduos, diferença essa marcada por fatores qualitativos e quantitativos dos elementos constituintes das instâncias em relação com algo que podemos chamar de história pessoal em conjunção com especificidades e singularidades de momentos estruturais e estruturantes pelos quais todos passamos no caminho de nos tornarmos membros da comunidade humana. Os elementos constituintes das instâncias são conteúdos ideativos qualificados de inconscientes, pré-conscientes e inconscientes. O que determina a qualidade desses conteúdos, ou seja, que sejam inconscientes, pré-conscientes ou conscientes é sua ligação (pré-consciente e consciente) ou falta de ligação (inconsciente) com representações verbais. Por sua vez, o que determina ou permite a passagem de conteúdos de um estado de inconsciência para um estado de consciência é uma distribuição de energia libidinal, portanto um fator quantitativo. Todos esses elementos de distinção entre um indivíduo e

414 Educação \& Realidade, Porto Alegre, v. 38, n. 2, p. 413-431, abr./jun. 2013 Disponível em: <http://www.ufrgs.br/edu_realidade> 
outro marcam a experiência psicanalítica como um trabalho com a diferença, na diferença e, também por isso, cada análise é uma experiência singular e única.

Como a consciência é concebida como pontual e um estado eminentemente transitório, o eu, enquanto instância a ela associada, não pode a ela se resumir. Na realidade, diz Freud, o eu não apenas não é redutível à consciência, como é, em grande parte, inconsciente ${ }^{3}$. Também não tem a profundidade que lhe é suposta, pois ainda que sendo uma diferenciação do isso, se limita à sua superfície. O eu é um efeito de superfície do isso.

Sendo o eu associado à consciência, o senso comum leva a crer que as funções anímicas mais elevadas, em relação a uma escala de valores éticos, têm acesso livre ao eu consciência. Porém, a experiência clínica demonstra que "[...] la autocrítica y la conciencia moral - o sea, funciones anímicas -, a las que se concede un elevado valor son inconscientes y producen, como tales, importantísimos efectos" (Freud, 1923, p. 2709).

A constatação de um sentimento inconsciente de culpa, que se apresenta de início como uma contradição em termos, faz supor que não somente os mais baixos, mas também os mais elevados valores morais podem permanecer inconscientes. O responsável por tal façanha é a instância psíquica que se diferencia do eu ao se produzir uma espécie de identificação distinta das que concorrem para a composição do eu: o supereu.

As identificações, das quais o eu é um precipitado, seguem o modelo evidenciado pelo luto do objeto perdido, observado em casos de melancolia. O eu faz uma reconstrução em si mesmo do objeto, substituindo a carga libidinal nele investida (carga de objeto) por uma identificação com o mesmo, mais precisamente com traços do objeto, restos que ficam quando este é descartado. As identificações que dão origem ao supereu seguem o mesmo modelo das que compõem o eu, porém elas incidem sobre algo muito mais abstrato, vamos dizer assim, denominado por Freud como instância parental, mais precisamente com o supereu dos pais, com todas "[...] las valoraciones perdurables que se han reproducido por este camino a lo largo de las generaciones” (Freud, 1989 , v. 22, p. 19). Herança da qual devemos nos apropriar, tais identificações têm lugar ao final do complexo de Édipo e se relacionam às demandas parentais feitas à criança no sentido educativo, civilizatório, de uma inserção social marcada por regras mais definidas, da adoção de recalques que marcam o pertencimento à família e, fundamentalmente, da saída do triângulo edípico através do reconhecimento da impossibilidade de nele permanecer e nele encontrar as satisfações de suas próprias demandas pulsionais e realização do desejo primordial representado pelo incesto. Nesse sentido, pode-se dizer que, estritamente falando, a educação se consuma nesse momento, com o assujeitamento à Lei do Outro ${ }^{4}$.

Educação \& Realidade, Porto Alegre, v. 38, n. 2, p. 413-431, abr./jun. 2013. 
Para Além da Justa Medida

Em Totem y Tabu (1981 [1912]), Freud coloca sob a forma de mito coletivo a origem desse sentimento de culpa tornado originário no mito individual do Édipo. Tal origem está associada aos sentimentos ambivalentes amor/ódio em relação ao pai assassinado da horda primitiva que, por serem opostos entre si, não podem conviver na consciência por esta não admitir a contradição. Como o tabu evoca o lado recalcado do par ambivalente, aquele que liberado inviabiliza a convivência em grupos, qual seja, os sentimentos agressivos, de destruição, Freud vê no tabu a origem da consciência, entendida como consciência moral enquanto percepção interna da repulsa causada por determinados desejos e relativos remorsos.

Por alguma razão, desconhecida daqueles que estão imersos nos tabus - tanto selvagens primitivos quanto neuróticos modernos - os sentimentos agressivos, o desejo de morte, no qual se inclui o incesto, são veementemente condenados e por isso expulsos da consciência. Sendo assim, não há necessidade de haver razão para a condenação uma vez que ela funciona impulsionada por uma força interior, o sentimento de culpa, que aparece como natural e de origem desconhecida. Não é outro o sentimento associado ao supereu.

A experiência clínica comprova como esse desdobramento do eu sobre si mesmo se manifesta na forma de extrema severidade, chegando a pedir-lhe que preste contas não apenas de ações como também de pensamentos, sentimentos e propósitos. É o preço cobrado pela civilização e a moral sem a qual a mesma não existe: nada mais que a renúncia aos impulsos e desejos mais profundos e antigos. A conexão entre moral e desejo se evidencia pela regulação do segundo pela primeira, através do sentimento de culpa inconsciente.

Lacan (1988) fala sobre o caráter exorbitante do sentimento de culpa - atuando sem que o sujeito saiba - como uma contribuição de grande originalidade da experiência freudiana para o campo da reflexão ética. Vejamos suas razões para tal afirmação.

Em primeiro lugar, cabe salientar que Lacan estabelece uma diferença entre ética e moral para marcar a especificidade da experiência psicanalítica nesse campo:

\begin{abstract}
A experiência moral como tal, ou seja, a referência à sanção, coloca o homem numa certa relação com sua própria ação que não é simplesmente a de uma lei articulada, mas sim de uma direção, de uma tendência e, em suma, de um bem que ele clama, engendrando um ideal de conduta. Tudo isso constitui, propriamente falando, a dimensão ética e situa-se para além do mandamento, isto é, para além do que pode apresentar-se com um sentimento de obrigação. É assim que creio necessário situar a dimensão de nossa experiência em relação à reflexão moralista (Lacan, 1988, p. 11).
\end{abstract}


A razão de Lacan postular uma diferença entre ética e moral é justamente apontar o sentimento inconsciente de culpa como um para além do dever relativo aos costumes e aos mandamentos. A colocação do inconsciente no campo da moral e da ética tem por consequência um questionamento a respeito do que tem sido considerado o eixo de suas reflexões desde Aristóteles - fundamentalmente as questões do bem e do mal, da obrigação e do dever. Lacan propõe a psicanálise como uma experiência ética por colocar o sujeito diante de questões que o levam a perceber o confronto, a contradição e o paradoxo existente entre a concepção de bem para a moral - e, portanto, para tudo que regula o coletivo - e um outro bem que se articula com o desejo inconsciente, seu desejo. Daí a importância do sentimento inconsciente de culpa.

A articulação entre desejo e culpa se dá pela lei, pelo supereu. Tal articulação aparece tanto na narração do mito do pai da horda primeva de Totem e Tabu quanto no mito edipiano onde Freud afirma que o desejo fundamental do ser humano é o incesto, sendo condição de sua realização o assassinato daquele que a ele se interpõe.

Como o desejo se refere ao objeto perdido enquanto tal, este se constitui como um bem para o sujeito em direção ao qual se orientam todos os seus desejos. Nesse sentido, diz Lacan, Freud opera uma inversão da moral tradicional ao afirmar que o Bem supremo do sujeito - em direção ao qual se dirigem suas ações, no sentido do princípio do prazer - é o objeto proibido, o tabu por excelência, o objeto do incesto. Portanto, há um Bem para o sujeito que é o avesso do bem da moral que ordena o domínio, ou até a supressão, do que está em jogo na realização desse Bem. Sendo assim, se a finalidade da análise - e podemos acrescentar, da educação - é colocada como sendo o domínio da pulsão, nos confrontamos com uma questão: em direção a que bem ela se dirigiria?

Lacan (1988) nomeia o objeto articulador entre ética e desejo de a Coisa, das Ding, resultado não passível de representação de uma divisão original do objeto que se localiza centralmente em relação ao mundo "[...] subjetivo do inconsciente organizado em relações significantes” (Lacan, 1988, p. 91), porém, em posição de exterioridade a esse mundo. Exterioridade porque alheia ao sujeito, estranha como o Outro originário do desejo, ela é dedutível da ideia de plenitude evocada pelo significante - sem a qual não haveria desejo (de plenitude) - que ao mesmo tempo desvela a falta. No inconsciente sua presença se dá por um representante de representação (Vorstellungsreprasentanz), como signo que representa a representação enquanto função de apreensão do bem que toda representação evoca, pelo simples fato de pressupor o fora de representação que é a Coisa. Portanto, o sujeito só pode se relacionar com seu bem através do sistema significante inconsciente, onde "[...] ele absolutamente não domina o sistema de direções, de investimentos, que regulam profundamente sua conduta" (Lacan, 1988, p. 92), domínio do discurso do Outro.

Educação \& Realidade, Porto Alegre, v. 38, n. 2, p. 413-431, abr./jun. 2013.

Disponível em: <http://www.ufrgs.br/edu_realidade> 
Para Além da Justa Medida

Dentro da referência do funcionamento psíquico pelo princípio de prazer ávido de repetição, a Coisa se situa fora, de onde introduz no inconsciente algo que é da ordem de uma lei. É como lei que a Coisa se apresenta enquanto experiência inconsciente. Porém, "[...] uma lei de capricho, arbitrária, de oráculo também, uma lei de signos em que o sujeito não está garantido por nada [...]. É por isso que esse Gute [bom], no nível do inconsciente, é também, e no seu fundo, o mau objeto" (Lacan, 1988, p. 93). Embora o sujeito não tenha notícias da Coisa - nem boa, nem má - nesse nível onde não há articulação possível. Aliás, ele trata de manter-se à distância da Coisa, se defende dela fazendo sintomas e sua defesa tem um nome, diz Lacan, e seu nome é mentira sobre o mal: "No nível do inconsciente o sujeito mente. E essa mentira é sua maneira de dizer a verdade acerca disso" (Lacan, 1988, p. 94). Freud se refere a essa mentira como próton pseudos, a primeira mentira.

E aqui estamos de volta à questão da verdade. Lacan faz referência ao não darás falso testemunho mosaico traduzindo-o para um não mentirás que evidencia o laço estruturante do desejo com a lei. É na medida em que o não mentirás pressupõe a possibilidade da mentira que esta se constitui como o desejo mais fundamental.

Por outro lado, há algo na mentira que a torna tão impossível quanto a verdade. A mentira, como o diz Arendt, é uma ação, e como toda ação promove seu agente a se mostrar quem é ao enunciá-la. Sendo assim, a mentira enquanto ação de fala não sabe o que diz, ou, em termos arendtianos, não sabe no que vai dar sua enunciação, posto que está sujeita à imprevisibilidade inerente a todo discurso. E no que ela vai dar, segundo a psicanálise, é na verdade por ela promovida e sinalada, a verdade do desejo. A fala é uma conjunção entre desejo e lei e "É nessa função antinômica, que a fala condiciona, entre o desejo e a lei que reside o móvel primordial que faz desse mandamento, entre os outros dez, uma das pedras angulares do que podemos chamar de a condição humana" (Lacan, 1988, p. 105).

A fala da lei, aquilo que ela enuncia, faz a existência da Coisa. O sujeito só percebe a Coisa através do enunciado da Lei e, como a Lei ordena que ele se mantenha longe da Coisa, é aí mesmo que o desejo se acende e arde, a Coisa ganha vida. É nesse sentido que o não cobiçarás aponta para o objeto proibido e, porque proibido, desejado.

Se a lei suscita e possibilita o desejo pela proibição, o sujeito do desejo se constitui enquanto tal pelo assujeitamento à lei, assim como a lei é o que mantém o desejo na falta da Coisa. Nesse sentido, a lei é, antes de tudo, a lei da castração, a lei do Outro que se impõe na linguagem, estando presente desde sempre para o sujeito e em decorrência de que o desejo pode se constituir. Para o sujeito a lei não é uma decorrência do crime e sim a porta de entrada para o que podemos chamar de uma das formas da condição humana em psicanálise - a condição de assujeitamento à lei. Por ser uma lei inscrita na linguagem, nela se articulam o impossível e a morte, componentes da castração, ou seja, a impossi- 
bilidade que marca o ser humano com uma incompletude estrutural relativa à perda de parte essencial de seu ser. Incompletude da qual ele não quer saber nada e mesmo que quisesse não teria acesso à verdade da castração em sua plenitude, uma vez que não há representação para o real perdido, assim como, não há representação para a morte e essa falta de representação é o próprio impossível.

É nesse sentido que Lacan afirma que a mentira, ou o mandamento que diz não mentirás, é a lei mais próxima à condição humana, pois da verdade só temos notícia parcialmente e a mentira é uma forma de dizer a verdade do desejo.

O desejo, em sua mais íntima relação com a Lei, leva inevitavelmente a conceber a psicanálise como uma experiência ética, pois de que se trata em uma análise é da depuração da questão do saber sobre a verdade do sujeito. De entrada, em toda análise o que está em jogo é um saber que o sujeito vai buscar onde supõe que vai encontrar. É como um especialista em verdade inconsciente que o analista é procurado. A equação entre saber e verdade se apresenta na medida em que o sujeito sofre de um desconhecimento de si, de não saber quais são seus verdadeiros sentimentos e desejos. Enfim, sofre de sua alienação ao desejo do Outro, que o impede de saber qual é o seu bem e como fazer o que é o melhor para si. Sua esperança consiste em que o analista saiba a verdade de seu desejo e que esta, quando lhe for comunicada, o libertará de todo sofrimento. De certa forma, isto é uma meia-verdade, pois a verdade do sujeito - embora não lhe seja comunicada - libera da alienação primordial ao desejo do Outro. E de meias-verdades em meias-verdades, o sujeito vai passando pela experiência da verdade fundamental - a de que não existe verdade inteira, pois parte do que a constituiria, a experiência direta com o real, foi perdido para sempre. A parte da verdade perdida para sempre vivemos como falta sem saber do que, uma vez que ao perdido não temos acesso, e só nos resta tentar representá-lo sem nunca consegui-lo.

É no sentido da experiência da falta, da condição humana de incompletude e de desamparo diante do impossível de saber sobre algo de útil, algo de eficiente sobre o desejo, que a psicanálise pode ser pensada como uma experiência ética sobre a verdade do sujeito. Quando vai em busca do saber do Outro acerca da verdade de seu desejo, o sujeito vai duplamente enganado. Seu primeiro engano é de que existe um saber objetivo sobre a verdade do desejo. Seu segundo engano é pensar que tal saber é comunicável e não localizável nele e sim no Outro, no analista. Digamos que o primeiro engano é da ordem da ilusão, e o segundo está a serviço de uma desresponsabilização do sujeito em relação a seu sofrimento.

É em direção à responsabilização do sujeito, quanto a seu sintoma, que aponta a ética da psicanálise. Responsabilização que implica em um posicionamento outro diante da realidade compreendida por laços discursivos que costumamos designar como relações sociais. Nas 
palavras de Lacan (1988, p. 374), "Se há uma ética da psicanálise - a questão se coloca -, é na medida em que, de alguma maneira, por menos que seja, a análise fornece algo que se coloca como medida de nossa ação - ou simplesmente pretende isso".

Uma vez que a hipótese do inconsciente supõe um sentido oculto às ações dos homens, a psicanálise trabalha em direção ao sentido da ação - direção que a coloca numa dimensão ética condensada por Lacan na pergunta: agiste de acordo com seu desejo? a partir da qual se delineia a única culpa imputável ao sujeito, qual seja, a de ter cedido quanto a seu desejo. Mas que significa ceder quanto ao desejo? Lacan responde:

O que chamo ceder de seu desejo acompanha-se sempre no destino do sujeito [...] de alguma traição. Ou o sujeito trai sua via, se trai a si mesmo, e é sensível para si mesmo. $\mathrm{Ou}$, mais simplesmente, tolera que alguém com quem ele se dedicou mais ou menos a alguma coisa tenha traído sua expectativa, não tenha feito com respeito a ele o que o pacto comportava, qualquer que seja o pacto [...] Algo se desenrola em torno da traição, quando se a tolera, quando, impelido pela ideia do bem - quero dizer, do bem daquele que traiu nesse momento - se cede a ponto de diminuir as próprias pretensões, e dizer-se - Pois bem, já que é assim, renunciemos à nossa perspectiva [...] entremos na vida costumeira. [...] Transposto esse limite, em que com um termo vinculei para vocês o desprezo pelo outro e por si mesmo, não há retorno. [...] não é esse um fato da experiência que nos mostra que a psicanálise é capaz de nos fornecer uma bússola eficaz no campo da direção da ética? (Lacan, 1988, p. 385).

Portanto, mais que uma diferença marcada pela ideia de normalidade, que aliás Freud já descartara, ou pela ideia de uma potência egoica capaz de controlar as pulsões após havê-las domesticado, a diferença entre uma pessoa que passou por um processo de análise e outra que não passou, parece apontar muito mais para as ações do sujeito no tocante ao próprio desejo, o que não deixa de implicar um certo saber a respeito de sua verdade. Porém, é um saber que está mais para o lado da ação, do saber fazer com isso que o constitui do que para um saber positivo, de consciência. Nessa linha de pensamento, o final de uma análise poderia ser proposto como o inverso de seu início, no qual o sujeito chega totalmente alienado quanto à verdade de seu sintoma, que está toda colocada no saber sobre isso do Outro e, sendo assim, numa posição de não responsabilidade em relação a seu sofrimento.

Aqui cabe um esclarecimento: não se deve confundir responsabilidade com culpa. Conforme vimos, o sujeito sofre de culpa, sente-se culpado ou age como se fosse culpado por algo que não sabe bem porque, ou atribui esse sentimento, quando o identifica, a algo que tem a ver com o bem, ou mal, do outro. A responsabilidade, ao contrário, exige um reconhecimento da verdade do desejo. Enquanto a culpa assume a 
forma de um comportamento (e não ação) moral que desresponsabiliza o sujeito quanto à verdade de seu desejo - cuja via vai num sentido, não raro, inverso a seu comportamento - a responsabilidade implica em enfrentar a ambivalência de sentimentos e a incompletude estrutural do sujeito. Para responsabilizar-se é preciso coragem, enquanto a culpa, o sofrimento moral, é considerado por Freud como covardia.

Portanto, a máxima lacaniana do não cederás quanto a teu desejo implica em responsabilização e aponta para um final de análise totalmente outro que um apaziguamento das pulsões. O responsabilizarse é resultado de uma mudança de posição diante do desejo do Outro. Conforme dito anteriormente, o sujeito no início da análise deposita no analista tudo que um dia depositou em seu Outro primordial, fundamentalmente a posição diante de seu desejo, ou seja, posição de objeto. Embora sua demanda seja no sentido de cura de um sofrimento, o que o sujeito realmente deseja é o desejo do Outro, ou seja, do analista que está ocupando esse lugar em sua economia psíquica, como o diria Freud. Para tanto, não pode sair de sua posição de objeto. Porém o analista está aí para não deixá-lo nessa posição (in)cômoda e sim para direcioná-lo no caminho de tornar-se sujeito de seu próprio desejo, resignificando a posição de objeto de gozo do Outro. $\mathrm{O}$ ato do analista vai direcioná-lo no caminho da ética do desejo, colocando-se ele no lugar de objeto do sujeito. Consequentemente, o sujeito é convocado a desinvestir o Outro do poder de senhor de seu destino ${ }^{5}$. Momento difícil de confronto com a dura realidade do desamparo da condição humana: não há quem responda por meu desejo, não há verdade absoluta, não existe Objeto que satisfaça o desejo, não existe o Bem supremo uma vez que a referência da deriva do desejo é a Coisa, o vazio de representação.

Quando trata da verdade no campo da moral, Arendt recorre a Sócrates, autor da proposição tida como o início da tradição do pensamento ético ocidental: é melhor sofrer o mal do que praticá-lo tomada pela autora para pensar a verdade, mas também para pensar a grande questão que se lhe colocou a partir dos fatos relativos ao totalitarismo alemão: é o pensamento capaz de evitar o mal?

Interessante de se notar é que tanto no aforismo socrático quanto na questão arendtiana a palavra que os remete ao campo da ética é $\mathrm{mal}$ e não bem, enquanto significante referente desse campo. Embora mal em contraposição a bem seja tão legítimo quanto este nas problemáticas e reflexões morais, e um pressupor o outro, é o bem - em direção ao qual devem se dirigir as ações segundo princípios que conduzem uma vida harmônica à felicidade - o grande significante da ética a partir de Aristóteles até Kant. Talvez porque, a partir de então, a tradição ética tenha passado a se constituir como prescrições do bem agir visando à felicidade, entendida como um bem alcançado através da virtude enquanto moderação das paixões. Para Aristóteles, o que permite a moderação é a racionalidade do homem. Racionalidade capaz de assegurar 
Para Além da Justa Medida

um caminho localizado na justa medida entre a indulgência e a privação, conforme recomendação verdadeiramente aristotélica dada por Freud em célebre passagem acerca da educação ${ }^{6}$.

O bem agir pode ser pensado como uma das decorrências do sutil deslocamento operado por Platão do significante belo, como ideia suprema que conduz à verdade, para a ideia de bem - que para os gregos significava adequado ou bom para. Há aqui um deslizamento do sem utilidade, o belo, para o útil, o bem/bom para.

Nesse sentido, localizo o recurso a Sócrates feito por Arendt em uma certa afinidade entre sua concepção de pensamento - que a meu ver, além de ser uma espécie de metodologia de trabalho, tem uma dimensão ética e política: ética que aponta, para além da justa medida, para a possibilidade da ação criativa que não visa a utilidade, da emergência do novo e da singularidade ${ }^{7}$ - e a moral socrática expressa no diálogo do dois-em-um.

Por outro lado, há um outro aspecto que leva Arendt a recorrer a Sócrates em Verdade e política, ao qual vou me ater no momento. Ela o toma como modelo, como tipo ideal - conforme expressão weberiana - enquanto exemplo que "[...] na sua própria particularidade, [...] tem o poder de revelar alguma coisa que ultrapassa essa particularidade, uma generalidade que não se poderia determinar de outro modo" (Vallée, 2003, p. 20).

No Sócrates cidadão de Arendt - enquanto aquele que está no ágora entre o povo - está o exemplo da possibilidade de se fazer política sem ser político, sem estar no palco político da pólis. O que Sócrates fazia era considerar todo outro como potencial parceiro de diálogo. Falava com todos, um a um, levando cada um a se apropriar de algo que já era seu, sua opinião - sua verdade -, que a partir de então passa a poder sustentar.

Pode-se dizer que, nesse sentido, o que Sócrates fazia era produzir cidadãos aptos a sustentar sua doxa em público, na ecclesia. Assim, "Sócrates é cidadão, não por causa do que ensina, teoriza, afirma ou aconselha; mas devido ao que faz; e o que faz é praticar a maiêutica no coração da cidade" (Vallée, 2003, p. 25). Vallée localiza aqui a origem do conceito ontológico de pluralidade arendtiano.

Ter em conta que somos vários, é, para Arendt, romper com o solipsismo metafísico, é não esquecer que o outro também não existe no singular, mesmo num diálogo, trata-se sempre dos outros, todo sentimento de realidade vem dos outros. Ninguém teria um mínimo de certeza quanto a suas percepções, inclusive acerca de si próprio, sem o reconhecimento dos outros ${ }^{8}$. Há, portanto, uma interdependência entre todos os iguais que, sem desconsiderar as singularidades, leva à responsabilidade política pelo mundo.

A ideia de pluralidade implica que cada um é o outro do outro, e esse fato está inscrito no ser humano na medida em que ele pensa, isto 
é, do ponto de vista socrático ele dialoga consigo mesmo e, nesse diálogo, não há apenas dois e sim vários dos quais o interlocutor interno é o representante. Portanto, essa concepção/proposta de pensamento, mesmo se dando na solidão, não exclui o mundo, o outro. "Esse diálogo do dois-em-um não perde o contato com o mundo dos seus semelhantes: estes, com efeito, são representados num dos eu com os quais eu mantenho o diálogo do pensamento ${ }^{9 "}$ (Arendt, 1972 apud Vallée, 2003, p. 27). É o outro em mim.

Outro aspecto importante em relação ao método socrático de diálogo e exame crítico, considerados como os fundamentos da moral ocidental, é que estes permitem pensar questões morais a partir de uma ética secular não apoiada em mandamentos divinos e promessas de castigos e recompensas. As proposições socráticas essenciais são duas:

1. Cometer a injustiça é pior que do que sofrê-la; quanto a mim, gostaria mais de a sofrer do que de a cometer (Górgias 469c, 489a, apud Vallée, 2003, p. 28).

2. Seria melhor servir-me de uma lira dissonante e mal afinada, dirigir um coro mal ensaiado, ou estar em desacordo ou oposição com toda a gente, o que estar comigo mesmo, sendo um, e de me contradizer (Górgias 482b, apud Vallée, 2003, p. 28).

Para Arendt, a primeira dessas proposições é confirmada pelo exemplo de Sócrates uma vez que sua tese afirma que o exemplo, a ação enquanto exemplo, é a única forma de preceito ético que, não sendo um imperativo, pode competir com os mandamentos morais religiosos. No entanto, a pergunta que se coloca é: como a proposição socrática pôde vir a obter o seu alto grau de validade e se colocar como origem da moral ocidental se os diálogos platônicos atestam o quanto a mesma não conseguia persuadir nem amigos nem inimigos?

Obviamente, isso se deve a uma espécie de persuasão um tanto excepcional; Sócrates decidiu empenhar sua vida por sua verdade - dar um exemplo, não quando compareceu o tribunal de Atenas, mas ao recusar-se a fugir à sentença de morte. Esse ensinamento pelo exemplo é, com efeito, a única forma de "persuasão" de que a verdade filosófica é capaz sem perversão ou distorção; ao mesmo tempo, a verdade filosófica só pode se tornar "prática" e inspirar a ação sem violar as regras do âmbito político quando consegue manifestar-se sob o disfarce de um exemplo (Arendt, 1979, p. 306-307).

Portanto, enquanto inspiração da ação humana, enquanto bússola que aponta um norte desejável para as ações do homem em deriva quanto a seu bem, ou seja, uma ética, Arendt sustenta que só uma ação exemplar pode ter maior ou igual força que um mandamento.

E qual é a diferença entre um exemplo e um mandamento?

Em princípio, tal como o coloca Arendt, o mandamento tem origem transcendente, fora do mundo dos homens e de suas relações -em-

Educação \& Realidade, Porto Alegre, v. 38, n. 2, p. 413-431, abr./jun. 2013.

Disponível em: <http://www.ufrgs.br/edu_realidade> 
Para Além da Justa Medida

bora incida muito precisamente sobre a vida cotidiana na qual se dão as relações humanas. A esse respeito Lacan (1988) aponta para o não cobiçarás mosaico onde aparecem todos os detalhes, são enumerados os objetos concretos sobre os quais recai a cobiça do homem e lhe são proibidos e que, por isso mesmo, desejados. A força do mandamento está justamente aí, no fato de se referir a algo que diz respeito diretamente ao desejo do homem, nos seus mínimos detalhes, sendo que, ao mesmo tempo, lhe é conferida uma origem transcendente. Isso só pode significar que existe, no além do mundo humano, um saber, uma verdade, ou um saber sobre uma verdade sobre o desejo do homem e sobre o que é melhor para ele, seu Bem. E mais, sobre como o homem deve agir ou deixar de agir em direção a esse Bem. Ao proibi-lo, o mandamento aponta para o desejo e prescreve o evitamento de sua realização. Em suma, existe uma relação estrutural entre a lei e aquilo sobre o que incide essa lei - o desejo do homem - e essa relação se explicita no mandamento. Os objetos proibidos, enumerados nos mandamentos, $\mathrm{e}$ as ações mais ou menos específicas às quais se referem, prescrevem a direção a ser tomada pela ação do homem. Pode-se dizer, então, que o mandamento aponta para o impossível do desejo ao dar forma à lei. Está aí para lembrar o que se deve e não se deve fazer em relação ao outro para que as coisas andem o melhor possível. E quanto ao exemplo? De onde vem sua força?

Se uma das forças dos mandamentos é sua origem transcendente, divina, o exemplo, ao contrário, diz respeito a seres encarnados ou ficcionais que têm suas ações e palavras evocadas a título de exemplo. $\mathrm{O}$ exemplo não é imperativo, não tem força de lei, sua verdade não é transcendente e pode sequer ser factual. Só podemos pensar que sua força, sua verdade, sua realidade, procede de sua origem, qual seja, a história e a poesia, como diz Arendt (1979, p. 307) citando Jefferson: “[...] imprimese um vívido e duradouro senso de dever filial na mente de um filho ou filha com maior eficácia mediante a leitura do Rei Lear do que com todos os áridos tomos de Ética e Teologia que já se escreveram". Não teria esta fórmula uma certa familiaridade com a do mito?

Segundo definição de Lacan, mito é "[...] o que dá formulação discursiva a algo que não pode ser transmitido na definição de uma verdade" (Lacan, 2008, p. 13). O exemplo, sob a forma da narrativa, da ficção, revela a verdade de um fato particular com força de uma verdade geral ou até universal. O mito, a ficção, se oferece à verdade para dar-lhe uma forma de se transmitir. Tanto em um quanto em outro, trata-se da transmissão de uma verdade que não encontra melhor maneira de se transmitir que a ficção. O Édipo é um mito, mas também pode ser um exemplo. É um mito porque transmite a verdade do desejo fundamental do ser humano sem falar que é disso que se trata, ou seja, que essa verdade nos diz respeito. É um exemplo, não porque se ofereça como modelo de ação a ser seguido, e sim porque sua verdade particular é generalizável, ela se oferece à identificação com a estrutura. Esta talvez 
seja a diferença essencial entre essas duas formas de narrativa: a função fundamental do exemplo é oferecer-se como modelo identificatório para uma conduta virtuosa ou uma conduta a ser evitada, ou ainda como conduta alternativa à moral dos bons ou maus costumes - como o exemplo de Antígona. O modelo é um bem e, nesse sentido, o exemplo, enquanto ação localizada no passado, está voltado para o presente e para o futuro. A função do mito é dar sentido a algo do presente - um desejo ou um aspecto da realidade cuja representação é problemática ou impossível - sem abordar diretamente a verdade que está em jogo, porém, transmitindo-a a nível inconsciente.

Tanto mito quanto exemplo têm uma estrutura que excede a moral. O mito, enquanto explicação da origem de hábitos ou afetos, a excede justamente porque é o ponto de origem da própria moral. O exemplo a excede porque o que está em questão é a própria moral - ele questiona e retifica ou ratifica uma mores. E aqui há uma diferença fundamental entre ambos: o mito se limita a dar sentido ao presente pelo passado coletivo ou individual - enquanto o exemplo se abre - quer seja no presente ou no futuro - para o uso singular de cada um, para a ação.

Porém, o mais importante aqui é estabelecer relações entre exemplo e mandamento. O mandamento, enquanto imperativo, não pode exceder a moral, pois ele é a própria moral sem explicações, a não ser sua suposta transcendência. Por sua inflexibilidade ele está aí para ser cumprido ou burlado. Porém, em sua inflexibilidade de verdade absoluta, há algo quanto ao mandamento que desvela toda crueza da verdade da moral, seu caráter de regra, sua contingência. Arendt fala sobre esse aspecto em relação ao totalitarismo nazista:

Foi como a moral se tivesse subitamente revelado na significação original da palavra como um lote de mores, de costumes e hábitos que se podiam mudar por um outro lote tão facilmente como se mudam as maneiras de estar à mesa de um indivíduo ou de um povo. Como é estranho e aterrador que subitamente tenha parecido que os próprios termos que nós utilizamos para designar estas coisas - a moral, com sua origem latina, e a ética, com a sua origem grega - nunca teriam querido dizer outra coisa que uso e hábitos (Arendt, 1965 apud Vallée, 2003, p. 72-73).

Como não se trata aqui de fazer uma análise do fenômeno do totalitarismo da perspectiva da psicanálise, vou me limitar a alguns poucos apontamentos. Antes, porém, cabe chamar a atenção sobre o fato de que o trecho acima citado deixa claro que Arendt não estabelece uma distinção entre ética e moral, tal como o faz Lacan. Porém, a autora aponta a distinção entre algo que regula as ações dos homens enquanto um conjunto de mores - que em decorrência da contingência que lhe é constitutiva, pode, em dados momentos, se desregular -, e algo que passei a chamar de uma ética do pensamento fundada na moral socrática.

Educação \& Realidade, Porto Alegre, v. 38, n. 2, p. 413-431, abr./jun. 2013.

Disponível em: <http://www.ufrgs.br/edu_realidade> 
Para Além da Justa Medida

Nas palavras de Arendt podemos ler a descrição da face obscura da instância moral que consiste o supereu freudiano. Como vimos, o supereu é descrito por Freud como um desdobramento do eu sobre si mesmo que condensa as identificações com o supereu parental, ou seja, as identificações com aquilo que ordena as ações do sujeito em relação a seu desejo em conformidade com um ideal. Se o ideal é a lei, quanto maior for a identificação com a lei mais o supereu será inflexível quanto às ações - e pensamentos e sentimentos - do sujeito. Porém, nem tudo é lei para o sujeito, existe o desejo, efeito dessa mesma lei que entra em conflito com ele. O que é proibido pelo supereu é o gozo do objeto proibido, isto é, o incesto entendido como a queda de todas as barreiras impostas pela realidade humana.

Porém, para além dessa face que orienta o sujeito em direção a um bem - não apenas do sujeito enquanto indivíduo na medida em que trabalha por sua conservação e bem estar, mas também do outro/Outro imprescindível para a realização de seus objetivos - há a face obscura do supereu que se liga ao eu pelo lado do isso, ou seja, das demandas pulsionais que ignoram o bem estar e instam o eu a ir em direção ao impossível da plena realização do desejo proibido. O imperativo dessa face do supereu é como o diz Lacan: Goza! Neste contexto, o gozo é o oposto do desejo. O desejo, em suspensão e deriva quanto a seu bem, constitui o sujeito e preserva o eu. O gozo ignora o bem do eu substituindo-o por seu próprio bem, que vai no sentido do aniquilamento do eu, na realização do objetivo primordial do princípio do prazer: retornar ao estado de plenitude, de ausência de tensão cuja representação é o irrepresentável: a morte. É a pulsão de morte que move o sujeito em direção ao gozo, o bem do supereu tirânico, como o define Lacan. É em direção ao bem do supereu tirânico, inimigo e possível usurpador do supereu egoico, que caminha toda ação que transpõe limites, quer em relação ao outro, quer em relação ao próprio eu do sujeito. E quando isso acontece, a moral é questionada e seu sentido pode se perder se não houver uma referência à lei.

É justamente aí, quando o sentido da moral dos mandamentos se perde, que ganha sentido recorrer às proposições socráticas que deslocam o fundamento da moral corrente dos mandamentos e o que vem com eles - castigo e constrangimento moral vindos de fora do sujeito e que pressupõe testemunhas - para uma moral fundada no pensamento. Esta moral secular recusa a ideia de crime sem testemunhas, o chamado crime perfeito, porque propõe o pensamento como uma experiência de diálogo interior que se passa na solidão da companhia de si mesmo. É por não querer conviver com um criminoso que não se comete um crime, uma vez que a consciência, um segundo eu que se manifesta como escrúpulo ou como censura em relação a um ato cometido, vai atormentá-lo. É por ter um segundo eu por testemunha que Sócrates exorta a que cada um seja conforme o que quer parecer ser, sendo ele mesmo sua própria testemunha quando em companhia apenas de si mesmo. Uma terceira proposição - deves ser verdadeiramente tal como queres 
aparecer - vem completar a proposta socrática de uma moral que prescinde do mandamento do castigo do Outro, mas não da existência do Outro, representado no diálogo do dois-em-um. Esse parecer que se quer ser é uma forma de ideal proposta por Sócrates como sendo possível de se manter enquanto tal, independentemente da coação do Outro que encarna a punição e a censura. Por outro lado, esse Outro se encontra presente no segundo eu - testemunha interior - sob forma da representação da pluralidade. Há muitas considerações possíveis quanto a esta questão que não cabem no âmbito restrito deste trabalho, porém, cabe assinalar que o grande valor da proposta arendtiana de retomar a moral proposta por Sócrates está no que aponta de possibilidade de haver uma moral de caráter não transcendente e tampouco contingente.

Intimamente ligada à questão das proposições morais socráticas está a questão do pensamento, central para Arendt. Assim como é possível agir segundo um bem falado por um eu interior que condensa as representações da pluralidade - sem constrangimentos de imperativos e promessas de castigos - é possível um pensar que não tem por objetivo a Verdade. Assim, o pensamento para Arendt tem por ideal a proposta, ou falta de proposta, socrática para a atividade do pensamento. Neste sentido é interessante examinar sua questão colocada em termos da capacidade do pensamento em evitar o mal. Talvez pudéssemos dizer da possibilidade do pensamento evitar o mal.

Caso a proposta de Arendt sobre o pensamento fosse a mesma da tradição de pensamento ocidental iniciada por Platão, sua questão seria incompreensível ou contraditória, uma vez que, esta está fundada na busca da Verdade. Já do ponto de vista da psicanálise, a atividade do pensamento se dá entre a percepção e a consciência. Na proposta do funcionamento psíquico através das relações entre as instâncias - eu, supereu e isso -, o pensamento aparece nas atividades pré-conscientes do eu. Como consequência dessa localização, segundo Freud, o pensamento estaria seriamente comprometido com os mecanismos de defesa do eu em busca da harmonia entre demandas e pressões, internas e externas a ele, de tal forma que se torna difícil, muitas vezes, discernir realidade de fantasia nos processos do pensamento.

Porém, pensamento para Arendt é outra coisa. Em princípio, tal como Sócrates, por não declarar como objetivo a verdade e tampouco o saber. O pensamento socrático, como pensamento crítico, não dá nada, só tira, não constrói, destrói, purga a atividade do pensamento dos preconceitos, das crenças mal fundadas, das verdades do senso comum não questionadas. A finalidade do pensamento, para Arendt, é a aprendizagem da capacidade pessoal de discernir o bem do mal em uma questão particular sobre a qual o mesmo se disponha: a capacidade de julgar. Em última instância, trata-se de uma atividade que tem um fim em si mesma e, por resultado, a aptidão para julgar, capaz de mergulhar quem pensa na maior perplexidade quando seu objeto de pensamento é o conteúdo de uma regra, uma vez que a regra em si não tem significado.

Educação \& Realidade, Porto Alegre, v. 38, n. 2, p. 413-431, abr./jun. 2013.

Disponível em: <http://www.ufrgs.br/edu_realidade> 
Para Além da Justa Medida

O pensamento crítico também tem por resultado a separação da regra em si de seu conteúdo e, dessa forma, pode colocar conteúdos nessa estrutura, ou seja, julgar o particular pelo geral. O que importa é que exista a regra, independente de seu conteúdo. O pensamento crítico não permite a adoção de uma regra sem sentido, assim como não vê sentido na mudança de uma regra sem que esta seja avaliada criticamente. Sendo assim, é antitotalitário e anticonformista. Podemos resumir de que se trata quanto ao pensamento para Arendt nas palavras de Vallée:

\begin{abstract}
Ao destruir tudo o que é pseudo-saber, Sócrates liberta um lugar. Arendt utiliza, para o mostrar, uma metáfora recuperada de Heidegger: a do "vento que varre". E o lugar libertado por essa vassourada é a capacidade de julgar, sendo o "juízo" usado por Arendt no sentido kantiano de "juízo reflexivo". Trata-se em suma da capacidade de refletir de novo, na primeira pessoa, por si mesmo. [...] $\mathrm{O}$ efeito do vento do pensamento é que uma vez varrido tudo aquilo em que se acreditava, pode erguer-se algo como um novo eu (Vallée, 2003, p. 40).
\end{abstract}

Isso posto, à pergunta colocada por Arendt nos termos é o pensamento capaz de evitar o mal?, da perspectiva de sua concepção de pensamento poderíamos responder que sim, no que ela coincide com a tese socrática de que a capacidade de julgar, como resultado do exame crítico, leva a uma apropriação, a uma identificação com o produto do depuramento do pensamento, que racionalmente só pode ser bom. Porém, de imediato algumas questões se colocam. Se opinamos que o pensamento, tal como o concebe Arendt, é resultado de uma espécie de tratamento do pensamento - não podemos nos esquecer que o método psicanalítico já foi comparado à maiêutica socrática - do qual resulta um eu capaz de julgar por si mesmo e decidir sobre seu próprio bem, teríamos que nos indagar acerca da necessidade de tal tratamento: se ele se faz necessário é porque o pensamento sofre. Qual seria a causa desse sofrimento? Por outro lado, concluindo que o pensamento sendo tratado traria grandes benefícios a cada um e a todos, como colocar na prática uma empresa que envolve a todos, um a um? Estas questões também concernem à psicanálise. A diferença é que, em psicanálise, existe uma teoria a respeito do que causa o sofrimento no pensamento e o significante mestre dessa teoria é inconsciente - que coloca um limite entre a psicanálise e os demais campos. Porém, a despeito desse limite e respeitando-o, penso que, embora a ética não coloque as coisas em termos de sofrimento moral ou psíquico, mas sim em termos de uma ideia específica acerca de felicidade presente na filosofia, notadamente aristotélica, pode-se tecer considerações no sentido de articular ideias arendtianas e psicanálise.

Uma consideração na linha das questões acima colocadas, que me parece importante, é sobre a problemática da atividade do pensamento em sua diferença nos dois campos em questão. Alguns pontos já foram apontados ao longo da discussão desta reflexão, vou apenas 
delimitar um pouco mais o problema. Quando Arendt propõe o pensamento como uma atividade nos moldes do dois-em-um socrático, cujo resultado é um eu capaz de julgar por si próprio, e busca reforço à sua proposição no significado da palavra consciência em alemão - que vem a ser saber comigo e por mim mesmo - está trabalhando no registro do que em psicanálise se chama de consciência enquanto epifenômeno da vida psíquica. Por outro lado, Arendt também fala em eu que, para a psicanálise, é uma instância do psíquico humano que trabalha com e é trabalhada por conteúdos conscientes e inconscientes, em sua maioria. A grande contribuição de Freud quanto à elucidação das ações humanas passa por essa descoberta de que o eu é em sua maior parte inconsciente e fundado sobre o desejo recalcado. Embora evidentemente não o diga da perspectiva da postulação de um inconsciente tal como o da psicanálise, Arendt assinala o caráter de um saber não-todo característico da ação: "Ao agir [...] é de fato verdade que nunca podemos saber realmente o que estamos fazendo" (Arendt, 2005, p. 193). Ora, se na ação o eu não pode estar seguro do que faz - e sendo a ação inseparável da palavra que a expressa e lhe dá existência - e do que diz, como garantir que o pensamento saiba o que está pensando? Nesse sentido, tanto Freud quanto Arendt colocam a questão da certeza possível quanto ao pensamento na capacidade de julgar que na teoria psicanalítica está bastante problematizada pelo funcionamento do princípio do prazer. Este assunto é bastante complexo e extenso, não é o caso de estendê-lo mais do que assinalar o quanto a proposição do inconsciente freudiano problematiza qualquer posicionamento acerca da consciência e do pensamento.

Em relação ao pensamento enquanto possibilidade de fazer barreira ao mal - e poderíamos dizer, ao gozo -, ainda há uma palavra a dizer. O que faz barreira ao gozo é o desejo, ou seja, um certo posicionamento diante do impossível imposto pela lei. Talvez o pensamento - enquanto atividade crítica de questionamento de sentidos dados - possa ser um anteparo para o mal uma vez que se trata de um possível destino da pulsão. Porém, o que parece interessante ressaltar no momento é que, tanto a ética do desejo da psicanálise quanto a ética do pensamento de Arendt, não contam com balizas nem tampouco com um nomos mas sim com uma referência à lei. Para a psicanálise trata-se da lei da linguagem que impõe o limite entre o representável e o irrepresentável e para Arendt trata-se da lei constituída através da depuração das ideias pelo livre debate ou embate no espaço público ou no espaço do dois-em-um. Portanto, tais éticas não se referem ao bom para, por não se tratar aqui de conteúdos normativos contingentes facilmente substituíveis, e sim de uma referência para a deriva do desejo e do pensamento. Referência que, em última instância, aponta para a radicalidade da experiência humana como fundada em sua condição de pluralidade - o fato de sermos todos iguais e ao mesmo tempo singulares, como o propõe Arendt - e no fato de que o sujeito dessa experiência se constitui no campo do Outro, referência para a pluralidade. 
No tocante à educação, ao que se passa entre adultos e crianças, pode-se dizer que a instância do supereu, como resultado do processo a que é submetida toda criança com o objetivo de torná-la civilizada, indica que não podemos desconsiderar o caráter de ambiguidade de afetos aí presentes que nos leva, como o aconselha Freud, a buscar a justa medida entre dois opostos igualmente desastrosos. Porém, como aponta Lacan, para além da justa medida está colocada a questão do desejo e sua ética. Não ceder quanto ao desejo, isto é, não desertar ou não renunciar à posição de sujeito, é condição para que o adulto possa vir a ocupar um lugar de exemplo de assujeitamento à Lei como referência identificatória, como aquele que ao ser confrontado com a questão agiste de acordo com teu desejo?, possa ter um sim como resposta. Exemplo de um saber fazer com isso que o determina, de um responsabilizar-se por seu destino, de uma boa companhia para si mesmo, da disposição para o pensamento como aprendizagem do julgar, de pertencimento ao campo do Outro que o constitui como ser de linguagem atravessado pelo impossível de tudo representar - o que torna toda educação nada mais que uma educação possível. Talvez resida aqui a dimensão ética da educação.

Recebido em 30 de outubro de 2012 Aprovado em 13 de abril de 2013

\section{Notas}

1 Tal como o esclarece a própria autora em nota introdutória ao texto.

2 Portanto, quando se fala em domínio das pulsões, está-se se falando em domínio da pulsão de morte, da agressividade que leva à destruição, assim como do incesto como realização da morte psíquica do sujeito.

3 El "Yo" y el "Ello" (Freud, 1981 [1923].

4 Outra consequência possível de se pensar é que o tempo de latência que se segue ao Édipo pode ser compreendido como um tempo de acabamento das identificações simbólicas que culminam na capacidade de abstração na adolescência que possibilitam o pensar a ética. Neste sentido, podemos dizer que há um segundo tempo de consumação de uma educação que se dá na adolescência.

5 Nesse sentido, talvez possamos pensar que uma análise é o questionamento de uma educação na medida em que interroga as identificações e recalques nela produzidos.

6 “[...] la educación tiene que inhibir, prohibir, sofocar, y en efecto es lo que en todas las épocas ha procurado hacer abundantemente. Ahora bien; por el análisis hemos sabido que esa misma sofocación de lo pulsional conlleva el peligro de contraer neurosis. [...] Entonces, la educación tiene que buscar su senda entre la Escila de la permisión y la Caribdis de la denegación [frustración]. Si esa tarea no es del todo insoluble, será preciso descubrir para la educación un optimum en que consiga lo más posible y perjudique lo menos. Por eso se tratará de decidir cuánto se puede prohibir, en qué épocas y con qué medios" (Freud, 1989, v. 22, p. 42). 
7 Fogaça, 2011.

8 Embora Arendt pareça estar aqui no registro que Lacan chamaria de imaginário, faz pensar que nesse outros, presentes no outro sem o qual minha existência não se confirmaria, está de certa forma presente um Outro simbólico trazido ao diálogo consigo mesmo pelo próprio pensamento.

9 ARENDT, Hannah. Le système totalitaire. In: ARENDT, Hannah. Origines $d u$ Totalitarisme: tomo III. Paris: Points Seuil, 1972.

\section{Referências}

ARENDT, Hannah. Le Système Totalitaire. In: ARENDT, Hannah. Origines du Totalitarisme: tomo III. Paris: Points Seuil, 1972.

ARENDT, Hannah. Verdade e Política. In: ARENDT, Hannah. Entre o Passado e o Futuro. São Paulo: Editora Perspectiva, 1979. P. 306-307.

ARENDT, Hannah. A Vida do Espírito: o pensar, o querer, o julgar. Rio de Janeiro: Relume Dumará, 2000.

ARENDT, Hannah. Trabalho, obra, ação! Tradução de Adriano Correia com revisão de Theresa Calvet de Magalhães. Cadernos de Ética e Filosofia Política, São Paulo, Faculdade de Filosofia, Letras e Ciências Humanas da Universidade de São Paulo, v. 7, p. 175-201, $2^{\circ}$ semestre 2005.

CORREIA, Adriano. Hannah Arendt. Rio de Janeiro: Jorge Zahar Editor, 2007.

FOGAÇA, Marcia Regina. Pensando a Condição Humana com Freud, Arendt e Lacan. 2011. 178 p. Tese (Doutorado em Educação) - Programa de Pós-Graduação em Educação, Faculdade de Educação, Universidade de São Paulo, São Paulo, 2011.

FREUD, Sigmund. Analisis terminable e interminable. In: FREUD, Sigmund. Obras Completas. 4. ed. Madrid: Editorial Biblioteca Nueva, 1981. Volume 3. Trabalho original publicado em 1937.

FREUD, Sigmund. Nuevas Conferencias de Introducción al Psicoanálisis: 34. Conferencia, esclarecimientos, aplicaciones, orientaciones. In: FREUD, Sigmund. Edição das Obras Completas da Amorrortu Editores. Buenos Aires: Amorrortu Editores, 1989. V. 22. Trabalho original publicado em 1933 [1932].

FREUD, Sigmund. Totem y Tabu. In: FREUD, Sigmund. Edição das Obras Completas da Amorrortu Editores. Buenos Aires: Amorrortu Editores, 1989. Volume 13. Trabalho original publicado em 1912-13.

LACAN, Jacques. O Mito Individual do Neurótico ou Poesia e Verdade na Neurose. Rio de Janeiro: Jorge Zahar Editor, 2008.

LACAN, Jacques. O Seminário: livro 7: a ética da psicanálise. Rio de Janeiro: Jorge Zahar Editor, 1998.

VALLÉE, Catherine. Hannah Arendt: Sócrates e a questão do totalitarismo. Lisboa: Instituto Piaget, 2003.

Marcia Regina Fogaça é psicanalista. Professora na FIT-Faculdade de Itapecerica da Serra, pesquisadora do LEPSI - Laboratório de Estudos e Pesquisas Psicanalíticas e Educacionais sobre a Infância - IP/FEUSP. Pesquisadora do LATESFIP - Laboratório de Teoria Social, Filosofia e Psicanálise - IPUSP/Departamento de Filosofia, São Paulo/SP.

E-mail:mfogaca@usp.br 